\title{
Hymenostegia viridiflora (Detarieae, Caesalpinioideae, Leguminosae), a new tree species from Cameroon
}

\author{
B.A. Mackinder ${ }^{1,2}$, J.J. Wieringa ${ }^{3,4}$
}

Key words

Caesalpiniaceae

conservation

Fabaceae

taxonomy

threatened species

Tropical Africa

\begin{abstract}
Anew species of Hymenostegia (Detarieae, Caesalpinioideae, Leguminosae) is described from Cameroon. Hymenostegia viridiflora has previously been confused with the type species of the genus, $H$. floribunda, but differs from it in having pale green to greenish yellow instead of lemon yellow petals, a broader upper part of the stipule, more numerous reddish veins on the white bracteoles and generally more numerous and narrower leaflets. As a consequence, the geographic range of true $H$. floribunda no longer includes Cameroon. Hymenostegia viridiflora is assessed as Vulnerable according to the criteria of IUCN.
\end{abstract}

Published on 15 May 2013

\section{INTRODUCTION}

Leguminosae is a species-rich family of angiosperms of cosmopolitan distribution (Lewis et al. 2005). The approximately 19500 legume species (Legume Phylogeny Group 2013) are divided among three subfamilies, Caesalpinioideae, Papilionoideae and Mimosoideae. Subfamily Caesalpinioideae is the smallest, comprising about 2250 species in c. 170 genera, recognised as four tribes, Cassieae, Cercideae, Caesalpinieae and Detarieae (Lewis et al. 2005).

Among the 82 genera of the Detarieae enumerated by Mackinder (2005, subsequently modified to accommodate an addition by Breteler 2011 and a reduction by De la Estrella et al. 2012a) is Hymenostegia s.l., a genus of small to large trees of tropical African forest. Seventeen species are currently assigned to the genus (Mackinder 2005, Wieringa \& Mackinder 2012) which is characterised by 1-many-jugate paripinnate leaves; showy persistent paired petaloid bracteoles in the upper part of the pedicel and woody, compressed, usually single seeded dehiscent pods. However, as presently delimited, Hymenostegia is not a natural group (Bruneau et al. 2000, Mackinder et al. 2010). Based on a suite of vegetative characters, only nine species may be congeneric with the type species $H$. floribunda. Among the herbarium vouchers received on loan as part of our wider revision of Hymenostegia s.I., it was apparent that when placed side by side, those that had been determined as $H$. floribunda by different legume workers together formed a morphologically diverse set of specimens. Amid that set, gatherings from Cameroon could readily be separated from the type of $H$. floribunda on the basis of several floral characters which was consistent with some variation in the leaves. We believe that the Cameroonian collections represent

\footnotetext{
${ }^{1}$ Herbarium, Library, Art and Archives, Royal Botanic Gardens Kew, Richmond, Surrey, TW9 3AE, United Kingdom; corresponding author e-mail: B.Mackinder@kew.org.

2 Tropical Biodiversity Group, Royal Botanic Garden Edinburgh, EH3 5LR, United Kingdom.

${ }^{3}$ Biosystematics Group, Wageningen University, Droevendaalsesteeg 1, 6708 PB Wageningen, The Netherlands.

${ }^{4}$ Naturalis Biodiversity Center (section NHN), Herbarium Vadense, Wageningen University, Generaal Foulkesweg 37, 6703 BL Wageningen, The Netherlands.
}

a previously unrecognised species of Hymenostegia which we describe here as $H$. viridiflora. Differences between $H$. viridiflora and $H$. floribunda are given in Table 1.

The formal description of $H$. viridiflora increases the number of Hymenostegia s.str. species to ten but the number of Hymenostegia s.str. species known to be native to Cameroon remains at three, $H$. viridiflora, $H$. felicis (A.Chev.) J.Léonard (1951) and H. pellegrinii (A.Chev.) J.Léonard (1951). The latter two were reported by Aubréville (1970) in his account of the caesalpinioid legumes in Flore du Cameroun where he also reported another sensu stricto species H. mundungu (Pellegr.) J.Léonard (1951) as occurring in Cameroon. However, the single specimen on which Aubréville (1970) based that country record (Letouzey 4543) has been identified by us as $H$. pellegrinii. By transferring the Cameroonian collections of $H$. floribunda to $H$. viridiflora, an element of the variation of the $H$. floribunda specimen set mentioned above has been removed. Nevertheless, some heteromorphy remains which we have yet to disentangle. We think it likely that true $H$. floribunda is restricted to Gabon and (probably) Equatorial Guinea where it was reported by De la Estrella et al. (2006) although of the few vouchers that we have seen from the latter country, none are adequate to confirm its presence there.

Of the three Cameroon native species only $H$. viridiflora is endemic. In a study predicting legume diversity patterns in western Central Africa, De la Estrella et al. (2012b) forecast that the locations in Cameroon where this new species occurs should be rich in both terra-firma and particularly in riverine lowland rainforest legume species. That $H$. viridiflora fits the area-habitat pattern predicted by De la Estrella et al. (2012b) serves as independent corroboration of the findings of the study because Hymenostegia species were not among the taxa modelled.

Hymenostegia viridiflora Mackinder \& Wieringa, sp. nov. Fig. 1, 2; Map 1

Diagnosis: Most closely resembling $H$. floribunda Harms but differing in several aspects including the colour of the petals which are pale green to greenish yellow (not lemon yellow); bracteoles which have 9-15 (not 5 or less) palmate dark veins from base and the part of the stipule above the point of 


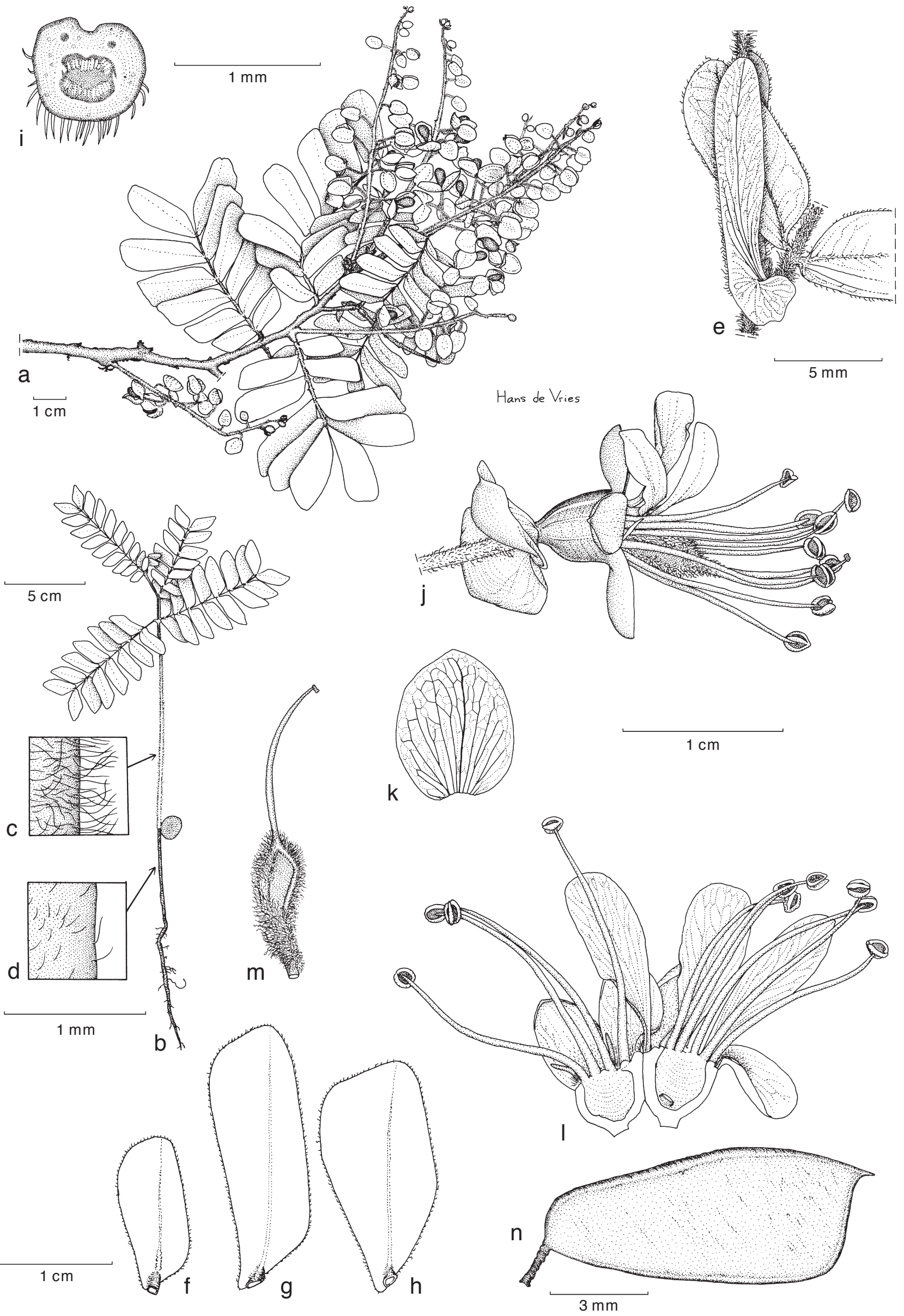

Fig. 1 Hymenostegia viridiflora Mackinder \& Wieringa. a. Flowering branch; b. seedling; c. epicotyl showing indumentum; d. hypocotyl showing sparse indumentum; e. stipule; f. leaflet from proximal pair; g. leaflet from middle pair; h. leaflet from distal pair; i. cross-section of stem; j. flower showing position of persistent bracteoles; k. bracteole; I. flower opened out; m. pistil; n. pod (a, e-m: van der Burgt 568; b-d: van der Burgt 621; n: van der Burgt 598). - Drawn by Hans de Vries. 
Table 1 Attributes of morphology and distribution that can assist in distinguishing $H$. viridiflora from $H$. floribunda.

\begin{tabular}{lll}
\hline & Hymenostegia viridiflora & Hymenostegia floribunda \\
\hline Leaves: length to width ratio & $1.5-2.5$ & $2-3$ \\
Number of leaflet pairs & $(4-) 6-10$ & $3-7$ \\
Leaflets: length to width ratio & $2-4$ & $1.5-2.5$ \\
Stipule: shape of upper part & narrowly oblong, $4-5$ times longer than wide & linear to filiform, $6-9$ times longer than wide \\
Bracteole: number of dark veins & $9-15$ & 5 or fewer \\
Petal colour & green & yellow \\
Distribution & Cameroon & Gabon \\
\hline
\end{tabular}
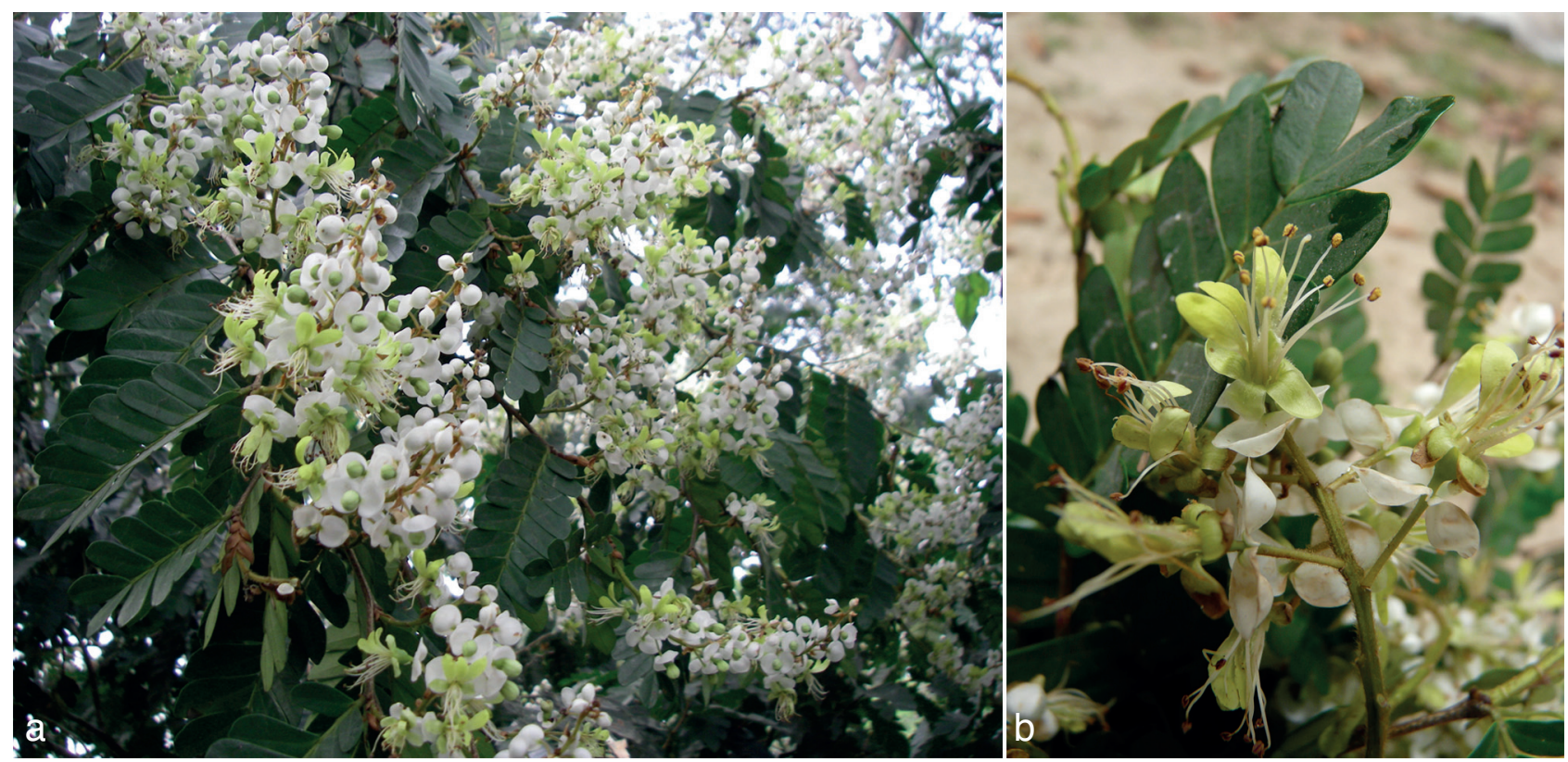

Fig. 2 Hymenostegia viridiflora Mackinder \& Wieringa. a. Leaves and inflorescences; b. close up of inflorescence showing detail and colour of flower parts (all: L.J. Pearce 11). - Photos by X.M. van der Burgt.

attachment which is narrowly oblong, four to five times longer than wide (not linear to filiform, six to nine times longer than wide).

Type. van der Burgt 568 (holo WAG; iso BR, C, G, K, MA, MO, NY, PRE, S, SCA, US, W, YA), Cameroon, South-West Province, Korup National Park, Science camp near $\mathrm{P}$ transect, tree above the kitchen, $\mathrm{N} 5^{\circ} 01^{\prime}, \mathrm{E} 8^{\circ} 48^{\prime}$, fl. 4 Jan. 2000.

Etymology. The species epithet refers to the conspicuous pale green to greenish yellow petals, a colour which to our knowledge has not been recorded in any other species of Hymenostegia. Other Hymenostegia species have lemon yellow petals.

Tree to $38 \mathrm{~m}$ tall, dbh $50-106 \mathrm{~cm}$; bole straight, somewhat fluted up to $2.5 \mathrm{~m}$ height, buttresses of several $\mathrm{dm}$ height extending to $5 \mathrm{~m}$ from the base of the tree, bark smooth. Twigs pale brown sericeous when young, glabrescent; hairs up to $2 \mathrm{~mm}$ long. Bud scales 5-6, caducous, distichous, proximal scale suborbicular, c. $2 \mathrm{~mm}$ diam, brown, coriaceous, not keeled, outer and inner surface glabrous except along the lower margins, the indumentum often hidden under the next overlapping scales, distal scales becoming progressively longer and relatively narrower, apical scale ovate, c. 6.5 by $4 \mathrm{~mm}$, not keeled. Stipules in pairs, free, seen in young foliage but then falling, auriculate at base, the auricle suborbicular, 3.5-9 $\mathrm{mm}$ across, $1.5-5$ $\mathrm{mm}$ from point of attachment to base, outer surface appressed pubescent, inner surface glabrous, margins ciliate, upper part of stipule oblong, $10-20$ by $2.5-5 \mathrm{~mm}$, outer surface pubescence (if present) confined to a central longitudinal band of appressed hairs, margins ciliate, inner surface glabrous, apex acute. Leaves ${ }^{1}$ paripinnate, dark green and slightly glossy,

Leaf and leaflet measurements were taken from mature leaves but not from those within the inflorescence. mature leaves $7-16.5$ by $3.8-8.1 \mathrm{~cm}$, about $2-3$ times longer than wide; petiole $1-3(-7) \mathrm{mm}$ long, rachis $5.6-12.2 \mathrm{~cm}$ long, channelled, glabrous or sparsely to moderately pubescent. Leaflets sessile in (4-)6-10 pairs, upper and middle leaflet pairs opposite, lower 2-3 pairs subopposite, largest leaflets usually the middle pair; largest leaflet $21-39$ by $7-18 \mathrm{~mm}, 2-4$ times longer than wide, usually oblong but sometimes becoming slightly wider in distal half, base asymmetric, proximal margin curving outwards towards the apex into an auricle, lower surface appearing glabrous with a hand lens (20x magnification) but sparse appressed puberulous indumentum visible under

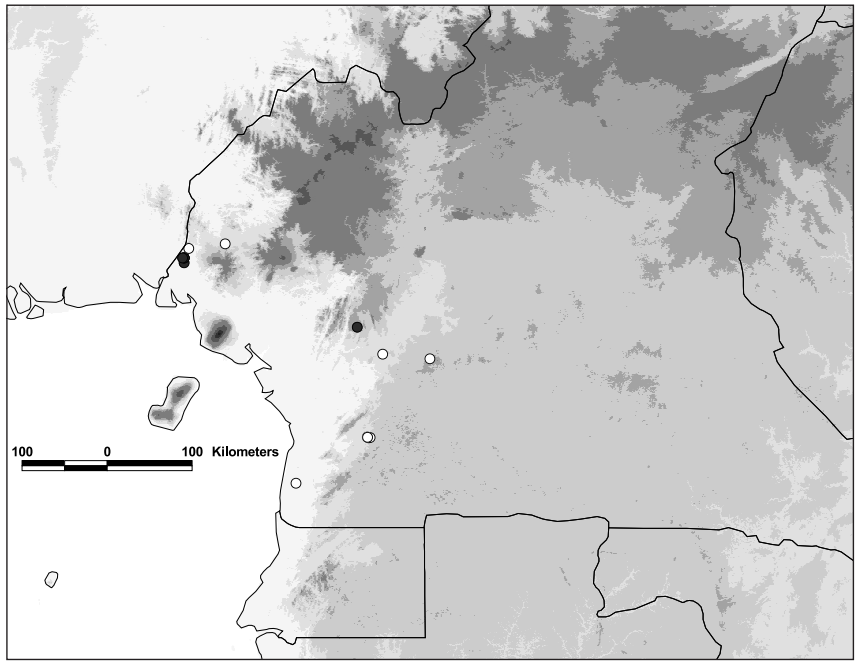

Map 1 Distribution of Hymenostegia viridiflora. Confirmed localities denoted by black-filled dots. Unconfirmed localities, denoted by open dots are shown to assist in the discussion of conservation status. 
a microscope, mid-vein sometimes pubescent, particularly in young foliage, fringing hairs c. $0.75 \mathrm{~mm}$ long, present particularly on the lower margins of young leaflets but sometimes absent in mature foliage; mid-vein central, prominent above and below for most of its length, becoming obscure just before the apex. Inflorescence a 10-26-flowered raceme, usually held erect, axis $3.8-13.5 \mathrm{~cm}$ long, including a peduncle $4-9 \mathrm{~mm}$ long with a moderate to dense indumentum of golden spreading hairs c. $1.25 \mathrm{~mm}$ long. Floral bracts ovate, $5-8$ by $1.5-4$ $\mathrm{mm}$, becoming smaller towards the apex of the inflorescence, inside glabrous, outside glabrous except for some hairs in the basal half sometimes confined to a patch just at the base, margins ciliate, hairs $0.5 \mathrm{~mm}$ long. Pedicels: portion of pedicel below bracteoles $6-10.5 \mathrm{~mm}$ long, hairs $0.5-1.5 \mathrm{~mm}$ long. Bracteoles opposite, ovate to obovate, $8.5-9.5$ by $7-8.5 \mathrm{~mm}$, with 9-15 reddish palmate veins emerging from the base, portion of the pedicels above the bracteoles $0.5-1 \mathrm{~mm}$ long, glabrous or with a few scattered hairs. Hypanthium 3-4 mm long, glabrous inside and out. Sepals 4, white with greenish and reddish lines, somewhat cucullate, reflexed or spreading, the adaxial sepal more belatedly so than the others, outside glabrous, inside basal half with an ovate hairy patch of erect hairs $0.7 \mathrm{~mm}$ long, apical margin with a few short hairs c. 0.1 $\mathrm{mm}$ long, adaxial sepals $5-6$ by $5-6 \mathrm{~mm}$, lateral sepals $3.5-6$ by $3-4 \mathrm{~mm}$, abaxial sepals $5-6$ by $3-4 \mathrm{~mm}$. Petals 5 of which 3 large, pale green to greenish yellow, adaxial petals narrowly spathulate, $8-11$ by $1.5-3 \mathrm{~mm}$, lateral petals narrowly spathulate $8-12$ by $1.7-4 \mathrm{~mm}$, abaxial petals inconspicuous, linear, $2-3$ by $0.1-0.3 \mathrm{~mm}$. Stamens 10 , filaments $9-17 \mathrm{~mm}$ long, white, anthers 1.2-1.4 mm long, yellow, slits with red margins. Ovary stipe 3.5-4.5 mm long, glabrous at base only, otherwise densely woolly, ovary $4-4.5$ by $2 \mathrm{~mm}$, glabrous faces, sutures densely woolly, ovules $1-2$. Pods held just above the crown leaves, compressed, $7.1-8$ by $3.3-3.9 \mathrm{~cm}$ at broadest part, triangular, broadest towards apex, upper suture not broadened, valve surface glabrous, immature pods with 10-14 conspicuous, fine, lateral nerves, not visible on mature pods, beak 3-5 $\mathrm{mm}$ long; single developed seed, discoid, $22-31$ by $13-23$ by $4-6 \mathrm{~mm}$ when fresh. Seedlings: hypocotyl $5.5-7.8 \mathrm{~cm}$ long, glabrous to sparsely pubescent, epicotyl $7-11 \mathrm{~cm}$ long, spreading pubescent, cotyledons suborbicular, c. 16 by $15 \mathrm{~mm}$, leaves first pair opposite, then all alternate, $8.3-11$ by $4.2-5.4$ $\mathrm{cm}$; leaflets sessile, in 6-8 pairs, opposite, largest leaflet at the middle of the leaf, $23-28$ by $8-10 \mathrm{~mm}$.

Distribution \& Ecology - Cameroon, SW and Littoral Provinces. Primary and little disturbed lowland forest, along river banks; 50-100 m.

Additional specimens examined. Both confirmed (flowering) and unconfirmed (fruiting or sterile) records are included here and plotted on the distribution map to aid in the discussion of conservation status.

Confirmed records (paratypes). CAMEROON, Littoral, Letouzey, R. 11088 (MA, MO, P, WAG), près Nkam, $10 \mathrm{~km}$ NNE de Ngambe (feuille IGN 1/200.000 Ndikinimeki), N4¹7', E10³8', 24 Jan. 1972 (fl). South-West Province, Burgt, X.M. van der 568 (G, K, S, SCA, WAG, YA), Korup National Park, Science Camp near $P$ transect, tree above the kitchen, $N 5^{\circ} 01^{\prime}$, E8 ${ }^{\circ} 48^{\prime}$, alt. 100 m, 4 Jan. 2000 (fl); Burgt, X.M. van der 597 (G, SCA, WAG), Korup National Park, road to Isangele, N4 $58^{\prime}, \mathrm{E}^{\circ} 48^{\prime}$, alt. 50 m, 26 Feb. 2000 (st); Burgt, X.M. van der 598 (G, S, SCA, WAG, YA), Korup National Park, Science Camp near $\mathrm{P}$ transect, tree above the kitchen, $\mathrm{N} 5^{\circ} 01^{\prime}, \mathrm{E} 8^{\circ} 48^{\prime}$, alt. $100 \mathrm{~m}, 11$ Mar. 2000 (fr); Burgt, X.M. van der 605 (G, SCA, WAG), Korup National Park, Science Camp near $\mathrm{P}$ transect, tree above the kitchen, $\mathrm{N} 5^{\circ} 01^{\prime}, \mathrm{E} 8^{\circ} 48^{\prime}$, alt. 100 m, 2 June 2000 (fr); Burgt, X.M. van der 621 (P, WAG), Korup National Park, Science Camp near $\mathrm{P}$ transect, tree above the kitchen, N5 ${ }^{\circ} 01^{\prime}, \mathrm{E} 8^{\circ} 48^{\prime}$, alt. 100 m, 2 Nov. 2000 (st); Pearce, L.J. 11 (BR, G, K, MO, P, SCA, US, W, WAG, YA), Korup National Park, North of P transect, NW plot, subplot 43XN, $\mathrm{N} 5{ }^{\circ} 01^{\prime}, \mathrm{E} 8^{\circ} 47^{\prime}$, alt. 100 m, 24 Feb. 2008 (fl).

Unconfirmed records. CAMERoon, Central Province, Letouzey, R. 11626 (K, P), 20 km NW Yaoundé, Mbam Menkoum massif, c. N357', E11 ²24', 18 Aug. 1972 (fr); Letouzey, R. 12253 (BR, P), 40 km NNE Eseka, inselberg W of Botmakak, c. N4 ${ }^{\circ} 00^{\prime}$, E10 $54^{\prime}, 7$ Dec. 1973 (st). South Province, McKey, D.B. C91/25/41 (K), Campo Forest Reserve, 20 km ENE of Ebodie, c. N2 ${ }^{\circ} 38^{\prime}$, E9 $59^{\prime}, 1$ Oct. 1991 (st); Parren, M.P.E. 56 (KRIBI, WAG), Ebom, N307', E1046', alt. 400 m, 1 Mar. 1997 (fl); Shu Neba, G.X. 4969 (WAG), Mvila, Ebom, Minwo catchment, TCP, Ecoll 1, plot M34, N307.2', E1044.5', alt. 425 m, 3 July 1999 (st); Shu Neba, G.X. 5140 (WAG), Mvila, Ebom, Minwo catchment, TCP, Ecoll 1, plot M32, N307.4', E1044.3', alt. 450 m, 10 Aug. 1999 (st); Wilde, J.J.F.E. de 12078 (KRIBI, WAG), Minwo-Area (D2), between Mekalat and Lolodorf, N306.8', E1045.1', alt. 470 m, 4 Dec. 1998 (st). South-West Province, Thomas, D.W. 8237 (MO), Banyu last moto, between Sekim and Banyu, N5¹0', E9 ${ }^{\circ} 14^{\prime}$, alt. 400 m, 25 Apr. 1988 (st); Cheek, M.R. 8271 (K, YA), Ndian, Ekundu Kundu, transect 9, between km 4 \& 6, along E-W river, $\mathrm{N5}^{\circ} 07^{\prime}, \mathrm{E} 8^{\circ} 51^{\prime}$, alt. 170 m, 29 Apr. 1996 (st).

Conservation assessment - Hymenostegia viridiflora is assessed here as Vulnerable VU B1ab(i,iv) according to the criteria of IUCN (2001). In IUCN terms, we consider the status of $\mathrm{VU}$ as a best estimate given that the assessment was not straightforward and that there is more than one plausible category to which the species might be assigned. The category proposed is based on confirmed (flowering) records from subpopulations into two locations, one in Korup National Park in SW Cameroon and the other near Nkam in the Littoral Province (denoted as closed dots on Map 1). From these records, we calculate a species EOO of $570 \mathrm{~km}^{2}$ suggesting a category of Endangered and AOO of $1460 \mathrm{~km}^{2}$ (at cell size $22 \mathrm{~km}^{2}$ ) suggesting VU. We have selected the lower category because the SW province population occurs in Korup National Park, a protected area where other than stochastic events, no other threats are known. We are also influenced away from Endangered $(E)$ and towards $\mathrm{VU}$ by the several unconfirmed records of the species (sterile or fruiting only collections) which were they confirmed, would result in a designation of Least Concern (LC). However, until we are able to confirm those records we do not consider LC, which is a category that also accommodates pantropical weeds, as an appropriate conservation status for this relatively poorly known species from the Cameroonian forest, a forest that is under considerable threat. We also considered the category of Data Deficient (DD) which is intended for species for which data are inadequate to determine a threat category with confidence. However, we judge that there exists sufficient data to arrive at an assessment, based on the combination of our current understanding of species distribution and knowledge of general levels of threat to forest habitats in Cameroon.

Notes - In the field flowers were noted as weakly scented (van der Burgt 568) or sweetly and strongly scented (L.J. Pearce 11). A colour change in the petals of fallen flowers was also observed in the field (van der Burgt 568) who recorded the fallen petals as 'dark red inside' and 'dirty white outside'. About 10 weeks is needed for flowers to develop into almost mature pods (van der Burgt 598). Once mature, pods audibly dehisce whilst still on the tree and the seeds are dispersed up to $18 \mathrm{~m}$ from the edge of the crown (van der Burgt 621). Following dehiscence the valves do not remain on the tree but fall to the forest floor (van der Burgt 621).

Letouzey 11626 (K, P) collected in Cameroon's Central Province, $20 \mathrm{~km} \mathrm{NW}$ Yaoundé on the Mbam Menkoum Massif consists of a vegetative collection mounted on the herbarium sheet with associated pods gathered from the forest floor in a capsule. The pods are hairy with a winged upper suture. Typically, pods of Hymenostegia s.str. species are glabrous without a winged upper suture. We suggest that Letouzey 11626 may represent a mixed collection with only the foliage belonging to $H$. viridiflora. We speculate that the pods gathered from the forest floor are a collection of Talbotiella breteleri (Aubrév.) Mackinder \& Wieringa (Mackinder et al. 2011) based on the combination of the pod morphology (indicating the genus Talbotiella) and the collecting locality which is the same as that of a known sterile collection of T. breteleri, Letouzey 11635 (YA). No other species of Talbotiella are known from the vicinity. 
Acknowledgements We would like to thank Hans de Vries for his illustration of $H$. viridiflora and Xander van der Burgt for permission to use his colour photographs. We also thank two anonymous reviewers for their helpful comments on the mss.

\section{REFERENCES}

Aubréville A. 1970. Flore du Cameroun 9. Légumineuses-Caesalpinoidées. Museum National d'Histoire Naturelle, Paris

Breteler FJ. 2011. Revision of the African genus Isomacrolobium (Leguminosae, Caesalpinioideae). Plant Ecology and Evolution 144: 64-81.

Bruneau A, Breteler FJ, Wieringa JJ, Gervais GYF. 2000. Phylogenetic relationships in tribes Macrolobieae and Detarieae as inferred from chloroplast trnL intron sequences. In: Herendeen PS, Bruneau A (eds), Advances in legume systematics 9: 121-149. Royal Botanic Gardens, Kew.

De la Estrella M, Cabezas FJ, Aedo C,Velayos M. 2006. Checklist of the Caesalpinioideae (Leguminosae) of Equatorial Guinea (Annobón, Bioko and Río Muni). Botanical Journal of the Linnean Society 151: 541-562.

De la Estrella M, Devesa JA, Wieringa JJ. 2012a. A morphological re-evaluation of the taxonomic status of the genus Pellegriniodendron (Harms) J.Léonard (Leguminosae-Caesalpinioideae-Detarieae) and its inclusion in Gilbertiodendron J.Léonard. South African Journal of Botany 78: 257-265.

De la Estrella M, Mateo RG, Wieringa JJ, Mackinder B, Muñoz J. 2012b. Legume diversity patterns in West Central Africa: Influence of species biology on distribution models. PLoS ONE 7, 7: e41526.
IUCN. 2001. IUCN Red List categories and criteria: Version 3.1. IUCN Species Survival Commission. IUCN, Gland, Switzerland and Cambridge, UK. Léonard JJG. 1951. Notulae systematicae 11. Les Cynometra et les genres voisins en Afrique tropicale. Bulletin du Jardin Botanique de l'État à Bruxelles 21, 3/4: 373-450.

Lewis GP, Schrire BD, Mackinder BA, Lock JM (eds). 2005. Legumes of the world. Royal Botanic Gardens, Kew.

LPWG 2013. Legume phylogeny and classification in the 21st century: Progress, prospects and lessons for other species-rich clades. Taxon 62 2: 217-248.

Mackinder BA. 2005. Detarieae. In: Lewis GP, Schrire BD, Mackinder BA Lock JM (eds), Legumes of the world: 69-109. Royal Botanic Gardens, Kew. Mackinder BA, Wieringa JJ, Lunenburg I, Banks H. 2010. Clarifying the generic limits of Talbotiella and Hymenostegia (Detarieae: Caesalpinioideae: Leguminosae). In: Ghazanfar SA, Lowry PP, Sonké B (eds), XVIIIth AETFAT Congress. Yaoundé, Cameroon: 43-56. Royal Botanic Gardens, Kew. Mackinder BA, Wieringa JJ, Van der Burgt XM. 2011. A revision of the genus Talbotiella Baker f. (Caesalpinioideae: Leguminosae). Kew Bulletin 65: 401-420.

Wieringa JJ, Mackinder B. 2012. Novitates Gabonensis 79: Hymenostegia elegans and Hymenostegia robusta, two new threatened caesalpinioid legume species from Gabon. Nordic Journal of Botany 30, 2: 144-152. 